SHORT REPORT

\title{
Why are women underused in the JECH peer review process?
}

\author{
M del Carmen Davo, C Vives, C Álvarez-Dardet
}

7 he quality of peer review is an essential part of the scientific process ${ }^{1}$ and nowadays its evaluation is an emergent area of research. ${ }^{2}$ The gender perspective is however, still rarely integrated in this kind of study.

There is empirical evidence about sex bias in choosing referees. Women are still less required by editors than men in peer review processes. ${ }^{3-4}$ As other studies have shown, male reviewers took significantly longer to return manuscripts than did their female counterparts and male reviewers recommend acceptance and rejection at higher rates than their female counterparts, who were more prone to revisions. ${ }^{5}$

The under use of women as reviewers seems then not justified by any quality criteria, as has been shown as well by the measurement of variables of time to answer and referees recommendations to authors. ${ }^{6}$ In addition, the promotion of gender parity in the peer review process could contribute to a reduction in the traditional invisibility of women in scientific knowledge development. . $^{-8}$

This study has been done with the main objective to detect gender bias in the Journal of Epidemiology and Community Health (JECH) peer review process and to identify differences, if any, between peer reviews with a gender perspective. The analysis includes the editors perceived quality of the review plus the other variables suggested by other studies as time to answer and referees recommendations to authors.

\section{METHOD}

The JECH database was retrospectively used for the analyses. It contains routine information about management of peer review process. The editors perceived quality of the review are assigned after the reception of the comments as background information if this referee is used again.

At first, all the referees registered by JECH in 2000 were identified. In this year, there were in total $837,69 \%$ men and $31 \%$ women. Then, we took a convenience sample choosing the first 100 men and the first 100 women identifying their sex by their name. Those referees recorded with initials or those one who were culturally not familiar to us (Asian or African countries) were not included in our sample.

The database used provided information about all the reviews made by these referees before and after 2000. All of them were included in the study. In total, these reviewers did 833 revisions, from 1992 until 2002 (52\% done by men and $48 \%$ done by women).

The following variables were used: sex as independent variable and time to answer (according with the difference in days between the date that the article was sent to the referee and the date of the referee's response), editors perceived quality (excellent, ${ }^{5}$ good ${ }^{4}$ normal, ${ }^{3}$ poor, ${ }^{2}$ not useful $^{1}$ ) and referee recommended decisions (no answer, ${ }^{5}$ acceptance without more revisions, ${ }^{4}$ minor revision, ${ }^{3}$ mayor revision, ${ }^{2}$ and rejection $^{1}$ ) as dependent variables.
A descriptive analysis was performed based on means and standard deviations, frequencies and comparisons by sex of the percentages, results in each interest variables were also explored. SPSS 10 was used for these analyses.

\section{RESULTS}

Among people selected for our sample (100 men and 100 women), men were required by the editor for 433 reviews and women were required for 400 reviews. All women answered with comments, but $28(6.5 \%)$ of the men did not $(p<0.001)$.

In the reviews done by these referees, there were no statistically significant differences between the sex of referees in time to answer (mean of days: men $=38.3(\mathrm{SD}=30.88)$; women $=38.89(\mathrm{SD}=26.87)$ days $)$ and editors perceived quality (mean of the score: $\operatorname{men}=3.8 \quad(\mathrm{SD}=0.66)$; women $=3.76(S D=0.61))$.

As table 1 shows, women considered more frequently than men the pertinence of doing major (women: $42 \%$, men: $39 \%$ ) or minor revisions (women: $28 \%$, men: $27 \%$ ). However, men rejected $(19 \%)$ and accepted $(15 \%)$ more articles than women (rejection: 17\%, acceptance: 15\%). None of these differences reached statistical significance.

\section{DISCUSSION}

There were less women than men in the peer review process of JECH during the period of time analysed in this study. However, the results show that there is not editorial justification for the under use of women as reviewers. There were not significant differences in the quality level of reviews or other peer review process management indicators between women and men. Also, women were more efficient than their male counterparts in accepting the requirement of the editor and considered other options before rejecting or accepting articles.

To properly confirm the hypothesis of men being more prone than women to reject and accept papers, ideally the same manuscripts should be reviewed by men and women under an experimental design. Another possible bias is that perhaps manuscripts were assigned differently by editors to men or women in relation to the subject.

Table 1 Referees recommended decisions

\begin{tabular}{llll}
\hline & $\begin{array}{l}\text { Men } \\
\text { Number (\%) }\end{array}$ & $\begin{array}{l}\text { Women } \\
\text { Number (\%) }\end{array}$ & Total \\
\hline Total & 433 & 400 & 833 \\
No answer & $28(6.5)$ & 0 & 28 \\
With answer & 405 & 400 & 805 \\
Major revision & $159(39)$ & $167(42)$ & 326 \\
Minor revision & $109(27)$ & $112(28)$ & 221 \\
Rejection & $75(19)$ & $68(17)$ & 143 \\
Acceptance & $62(15)$ & $53(13)$ & 115 \\
\hline & & & \\
\end{tabular}


Although this study cannot answer these questions our results confirm the trend observed in other studies ${ }^{45}$ and also add that male reviewers did not have better scores that their female counterparts in the other indicators related with time to answer and editor perceived quality.

This study suggests the existence of gender bias in JECH. Increasing women visibility in the peer review process could contribute to the amelioration of such a bias, but only partially. Peer review is mostly an anonymous activity, and it is not generally considered in the usual evaluations of scientific activity. Not only are women affected by invisibility, the peer review process is too. That is why senior, older and busy professionals-often male-usually have lower interest in collaborating as reviewers and usually get lower scores when the quality of the review process (acceptance rates, time to answer) is assessed. ${ }^{2}$ A policy of only increasing the participation of women in journals peer review could, in isolation, have perverse effects. Under the glass ceiling we could have women contributing anonymously to improve papers. So, what perhaps should be advocated is the promotion not only of women, but also of the visibility of the peer review activity in academic health sciences.
Authors' affiliations

M del Carmen Davo, C Vives, C Álvarez-Dardet, Campus Sant Vicent Raspeig, Alicante University, Alicante, Spain

Correspondence to: Carmen Vives, Campus Sant Vicent Raspeig, Alicante University, Alicante 03080, Spain; carmen.vives@ua.es

Accepted for publication 3 April 2003

\section{REFERENCES}

1 García A, Plasencia A, Fernández E. La calidad de las evaluaciones de manuscritos en Gaceta Sanitaria. Gac Sanit 2002;16:244-9.

2 Godlee F, Jefferson T. Peer review in health science. London: BMJ Books, 1999.

3 Miqueo C, Tomás C, Tejero C. Perspectivas de Género en Salud. Madrid: Minerva Ediciones, 2001

4 Gilbert J, Williams $E$, Lundberg $G$. Is there gender bias in JAMA's peer review process? JAMA 1994;272:139-42.

5 Dickersin K, Fredman L, Flegal K, et al. Is there a sex bias in choosing editors? Epidemiology journal as an example. JAMA 1998;280:260-4.

6 Harding S. Ciencia y Feminismo. Madrid: Ediciones Morata, 1996

7 Colomer C, Peiró R. ¿'Techos de Cristal y escaleras resbaladizas? Gac Sanit 2002; 16:358-60.

8 Schiaffino A, García M, Fernández E. Autoría y presentación de resultados según el género en 4 revistas biomédicas españolas. Gac Sanit $2001 ; 15: 251-4$.

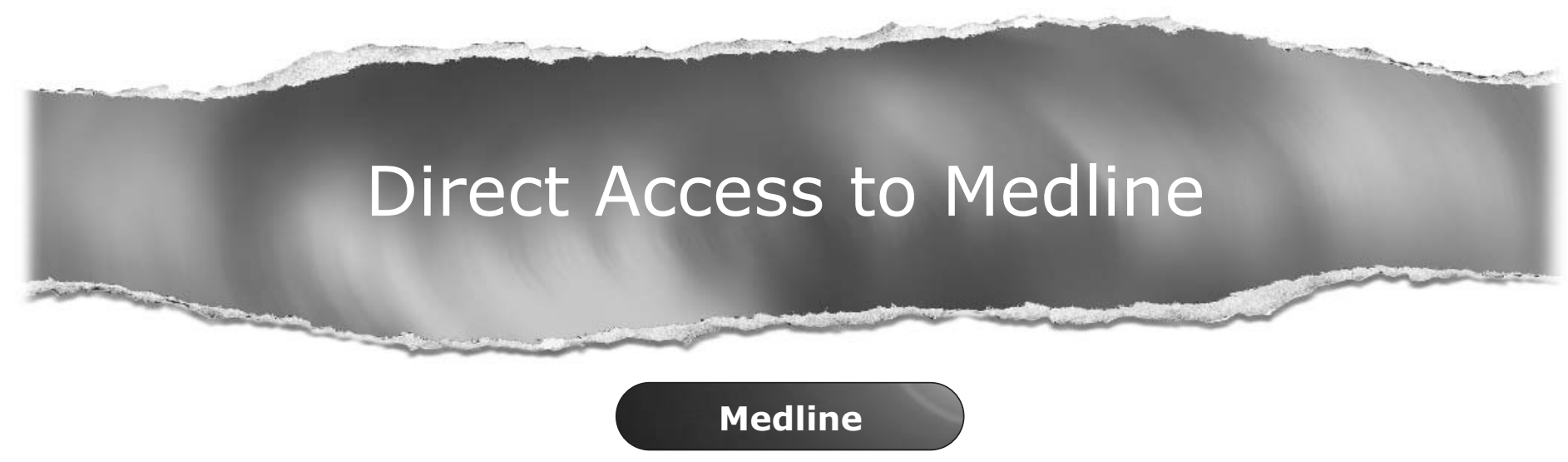

Link to Medline from the homepage and get straight into the National Library of Medicine's premier bibliographic database. Medline allows you to search across 9 million records of bibliographic citations and author abstracts from approximately 3,900 current biomedical journals.

\section{www.jech.com}

